АЛИКПЕРОВА Наталья Валерьевна - кандидат экономических наук, старший преподаватель департамента социологии, истории и философии Финансового университета при Правительстве РФ (125993, Россия, г. Москва, Ленинградский пр-кт, 49); ведущий научный сотрудник лаборатории исследования поведенческой экономики Института социально-экономических проблем народонаселения РАН (117218, Россия, г. Москва, Нахимовский пр-кт, 32; natalie_danilina@mail.ru)

\title{
ЭКОНОМИЧЕСКАЯ НРАВСТВЕННОСТЬ - ФУНДАМЕНТ УСТОЙЧИВОГО РАЗВИТИЯ СТРАНЫ И ОБЩЕСТВА
}

Аннотация. Экономическая жизнь современной России ставит множество острых вопросов, среди которых особую значимость приобретает проблема созидания в обществе и экономике нравственности, которая является фундаментом устойчивого, полноценного, эффективного развития любого государства. Актуальность данного вопроса обостряется на фоне тех проблем, которые мы наблюдаем в России в последние десятилетия: это высокий уровень экономической преступности и экономической эксплуатации, возникающий в результате алчности и эгоизма некоторых представителей бизнеса, в т.ч. иногда и не без помощи государственных деятелей; повсеместная коррупция; рост теневой экономики; падение нравственных устоев; снижение уровня образования, здравоохранения, науки, культуры.

Ключевые слова: экономическая нравственность, экономика, общество, финансовая грамотность, экономическое развитие

$\Pi$ еред нашей страной, а возможно, и перед всем миром стоит актуальнейшая проблема - проблема нравственности, нравственности в экономике. Общество только начинает задумываться над этим вопросом: у кого-то он вызывает недоумение, у кого-то - поддержку. Единого мнения по этому поводу пока нет.

Еще древнегреческий мыслитель Аристотель в IV в. до н.э. пришел к выводу: «Природа дала человеку оружие - интеллект и нравственность». Если в результате осуществления не одной научно-технической революции в развитии общественного интеллекта сомнений нет, и эволюция интеллектуального компонента очевидна, то наличие нравственной составляющей вызывает много вопросов.

Экономика и нравственность... Казалось бы, что между ними общего? Первое из этих двух понятий - явление сугубо материальное, отражающее процесс товарно-денежного производства в результате взаимодействия основных хозяйствующих субъектов и выражающееся в объективных макро- и микроэкономических показателях эффективности их деятельности. Второе понятие традиционно связывают с духовной сферой жизни общества, с определенными этическими и моральными нормами поведения людей; это критерий, который показывает, на каком уровне развития находится общество.

Но возможно ли ведение хозяйства в рамках нравственности? Сомнений нет. Однако на практике свободная воля индивида в ведении своего хозяйства оказывается настолько извращенной, что вызывает различного рода негативные последствия в виде череды кризисов, которые мы наблюдаем в конце XX начале XXI в.

Безмерное стремление к обогащению определенной части населения - вот краеугольный камень всех проблем человечества. Безнравственное общество характеризуется неэффективной экономикой [Швецов 2011: 3].

Профессор В.А. Ефимов называет подход, по которому устроено наше общество, счетно-финансовым. Это такой подход, при котором все действия ока- 
зываются оправданными, если они приносят максимальную прибыль. Такой подход приводит к разграблению всех ресурсов долгосрочной перспективы, не имеет стратегической направленности ${ }^{1}$.

Давно уже общепризнано, что нравственные проблемы возникают на рынке ежедневно и ежечасно. Это не только проблемы экономической преступности и экономической эксплуатации, возникающие в результате алчности и эгоизма некоторых предпринимателей, в т.ч. иногда и не без помощи государственных деятелей. Безнравственность создает негативный синергетический эффект в виде коррупции, теневой экономики, падения нравственных устоев, снижения уровней образования, здравоохранения, науки, культуры.

Нравственные проблемы присутствуют в повседневной управленческой работе, в процессе принятия решений менеджерами, рабочими, руководителями. И это происходит во всем мире и включает такие проблемы, как коррупция, охрана труда и безопасность на рабочем месте, система найма и увольнения работников, права наемных работников, преступность «белых воротничков», различные виды дискриминации, надежность и безопасность для здоровья производимой продукции, справедливая оплата труда 2 .

Подобные нравственные дилеммы характерны и для макроэкономического уровня. Они возникают, когда правительства и государственные органы, международные организации и корпорации, принимая какие-то экономические решения, тем самым воздействуют на общество, окружающую среду (например, оправданы ли высокие темпы экономического развития, если это загрязняет окружающую среду?), распределение доходов, социальное расслоение и Т.Д.

По данным Глобального отчета о богатстве, представленного в 2017 г. научноисследовательским институтом Credit Suisse, 45,9\% всех богатств (активы на сумму более 1 млн долл. на 1 чел.) сосредоточены в руках $0,7 \%$ взрослого населения нашей планеты, тогда как 70,1\% взрослого населения имеют в своем распоряжении всего лишь 2,7\% богатств (активы на сумму менее 10 тыс. долл на 1 чел.) ${ }^{3}$. Расслоение колоссальное.

Существует много причин для того, чтобы общество стремилось поддерживать высокие нравственные принципы и нормы. Прежде всего, это становление молодого поколения, перед которым стоит выбор жизненных ориентиров, выбор профессии и которое является стратегическим ресурсом формирования общества будущего. А что сегодня знают молодые люди о профессиях? Имеют ли они представление о рабочих специальностях? Присутствует ли уважение к данным специальностям? И что молодежь ставит перед собой целью в реализации себя как профессионала?

Сегодня молодые люди однозначно знают, что труд самых уважаемых в любой стране работников - учителей и врачей - является одним из самых низкооплачиваемых, а размер пенсий вышедших на заслуженный отдых людей, отдавших все силы государству, - ниже прожиточного минимума; что все государственные структуры (органы власти, полиция, ГИБДД, СЭС и т.п.) ни во что

\footnotetext{
${ }^{1}$ Нравственность в экономике. - Официальный ресурс Профессионалы.rи. Доступ: https://professionali. ru/Soobschestva/kak_zhit_vmeste_i_doveryat_drug_drugu/nravstvennost_v_ekonomike/ (проверено 18.06.2018).

2 Нравственность в экономике. - Официальный ресурс VIP Форекс. Доступ: http://vip4ex.ru/60nravstvennost-v-ekonomike.html (проверено 18.06.2018).

3 Global Wealth Report 2017: Where Are We Ten Years after the Crisis? - Официальный сайт Credit Suisse. URL: https://www.credit-suisse.com/corporate/en/articles/news-and-expertise/global-wealthreport-2017-201711.html (accessed 18.06.2018).
} 
не ставят личность человека, если он не относится к номенклатурной и другим элитам.

Говоря об экономических критериях, мы обращаем внимание на такие показатели, как инфляция, уровень ВВП, уровень безработицы, уровень жизни и др. Однако пока мало кто задумывался о таком критерии, как уровень нравственности в экономике.

В рамках экономической парадигмы неоклассического мейнстрима нравственность как экономическая категория, увы, не исследуется. По крайней мере, термины, используемые для обозначения таких «непрагматических» качеств с ярко выраженной нравственной основой, как справедливость, совесть, честь, доброта, сострадание, взаимопомощь, патриотизм и т.д., в современных экономических трудах и учебниках практически не встречаются. Вместо этого в них идет речь о максимизации индивидуальной прибыли/полезности ради удовлетворения потребностей человека.

Нравственность в обществе вносит в экономику этого общества «ограничитель» безграничных потребностей, когда по экономическим законам этого «ограничителя» нет, а существует всепоглощающий эгоизм каждого, приводящий, по мнению А. Смита, к всеобему развитию. Однако, как видно из практики, такое отношение имеет ряд негативных последствий, в частности, экологические проблемы на планете, паразитирование некоторых слоев общества, целых государств, увеличение неравенства в обществе, энергетические, продовольственные, демографические, миграционные и другие проблемы цивилизации.

Следует отметить, что не экономика двигает общество, а общество - экономику, т.к. не будь общества, не было бы и экономики. И, исходя из этого, уровень нравственности общества играет важную роль в том, в какую сторону и как будет двигаться экономика в целом, будет ли она иметь большие спады и подъемы или будет ближе к своему тренду, как будет выглядеть этот тренд.

Нравственность в обществе напрямую влияет на качественные процессы в экономике общества, что влечет за собой повышение конкурентоспособности производимой продукции, а это важнейший фактор движения экономики в целом. Лидерские качества без нравственного содержания приводят к застойным явлениям в общественном развитии, а их закрепление законодательной базой приводит к деградационным процессам.

Можно привести множество примеров безнравственности в экономике, в бизнесе.

Когда человек планирует свой бизнес, о чем он мечтает? Осчастливить человечество? Выпускать самые качественные продукты питания, чтобы люди были здоровы? Построить дома на века, чтобы люди жили, радовались и добрым словом вспоминали строителей? Делать мебель, цена которой будет возрастать из поколения в поколение?

Нет! Бизнесмен в первую очередь думает о прибыли, вернее, о наживе, чтобы как можно быстрее обогатиться. Неоспорим тот факт, что экономика эффективна тогда, когда она приносит прибыль. Но все ли пути к достижению прибыли оправданы? Так, бизнесмен обязан заботиться не только о развитии бизнеса, но и о сотрудниках, которые развивают этот бизнес, приносят прибыль, сверхприбыль. Другими словами, основой любого бизнеса должен быть моральный долг перед каждым стейкхолдером. Отношение к сотрудникам зачастую безнравственное. Можно ли ждать от сотрудников при таком подходе преданности компании, соучастия, стремления к развитию? Ответ очевиден. Нельзя человека делать просто орудием производства и лишать его средств к существованию. Это требования человеколюбия. Человека нельзя ставить ниже вещей, ради которых организована хозяйственная деятельность. 
Изначально начинающего бизнесмена на безнравственную дорожку ставит коррупция. Достоверной статистики о масштабах коррупции нет. Но достаточно посмотреть, как живет коррупционер, и все станет ясно. Ни одна заработная плата, даже самая высокая, не соответствует уровню жизни, который ведет коррупционер. Можно ли эффективно ней бороться, создавая десятки служб и комиссий, тратя множество общественных ресурсов, если на этом фоне не менять отношения людей к жадности, зависти, желанию повелевать другими людьми, удовлетворять свои любые прихоти, страху остаться без средств к существованию или «упасть» до уровня российского МРОТа?!

Нужно ли беспокоиться о повышении финансовой грамотности граждан, если зачастую эта грамотность - не во благо?

Финансовая грамотность - это не просто способность брать кредит так, чтобы непременно его отдать, не показывать ПИН-код от карточки незнакомцу и ни за что не верить депозиту в $20 \%$ годовых при инфляции $2 \%$. Финансовая грамотность - это одна из человеческих добродетелей.

Главный смысл финансовой грамотности - человеческий, а не финансовый. Моральный, а не материальный. Он состоит в том, чтобы по собственной вине (это не всегда полностью зависит от самого человека) не оказаться в бедности, не разориться, не оставить долгов детям. Он состоит в том, чтобы, если получится, честно (это непременное условие!) улучшить свое материальное состояние, распоряжаться своим состоянием так, чтобы не финансировать войны и убийства, а вкладываться в медицину, научные исследования или благотворительность. И в основе всей этой цепочки стоит нравственность. Ибо если ее нет, сама по себе финансовая грамотность не может считаться однозначным благом.

Люди безнравственные, зарабатывающие состояния с помощью финансовых махинаций, отмывающие грязные деньги, обманывающие клиентов за счет хитрых схем, по-своему финансово грамотны. Но они используют свои навыки во зло.

Финансовые знания - важное оружие современного человека. Возможно, одно из самых важных. Но пользоваться этим оружием, как и всяким другим, можно по-разному. Можно защититься, а можно убить. Можно познавать мир, помогать людям или просто жить в свое удовольствие, а можно отнимать такую возможность у других ${ }^{1}$.

К большому сожалению, сегодняшние реалии российского олигархического капитализма в массовом сознании укладываются в простую формулу: «Чтоб у нас все было, и чтобы нам за это ничего не было!» Капитал боится отсутствия прибыли или слишком маленькой прибыли, как природа боится пустоты. Но раз имеется в наличии достаточная прибыль, капитал становится смелым. Обеспечьте $10 \%$, и капитал согласен на всякое применение, при $20 \%$ он становится оживленным, при $50 \%$ положительно готов сломать себе голову, при $100 \%$ он попирает все человеческие законы, при $300 \%$ - нет такого преступления, на которое он не рискнул бы, хотя бы под страхом виселицы.

У каждого из нас есть умение с детства различать нравственное и безнравственное, поэтому гораздо проще в основу жизни и ее составляющих, в частности финансовой системы, заложить нравственные основы. Мало того, очень важно понимать, что нравственность даст экономике столь необходимые «ограничительные механизмы» наших потребностей, что сделает, в свою очередь, цены на ресурсы более низкими. Нравственность в экономике позволит восполнять некоторые ресурсы, а другие - снова перерабатывать. Человечество получит иную мотивационную базу для экономии, эффективного использова-

\footnotetext{
1 Человек, не обезображенный деньгами. - Официальный сайт Банки.ру. Доступ: http://www.banki. ru/news/columnists/?id=10334893 (проверено 18.06.2018).
} 
ния ресурсов, сокращения издержек и внедрения прогрессивных технологий, умение мыслить стратегически.

То общество, в котором живет каждый из нас, есть синергетический эффект «эффектов выборов каждого». «Ни одна капля не думает, что виновата в наводнении». Другими словами, мы сами сделали то, что мы имеем, потому что не думали о последствиях каждого выбора, а в сумме получился негативный синергетический эффект в виде коррупции, теневой экономики, падения нравственных устоев, снижения уровня образования, здравоохранения, науки, культуры. Беда в том, что эти процессы развиваются, пока общество не поразит долгосрочный глубокий социальный кризис, выход из которого будет ясен каждому. Но есть другой путь - путь целенаправленного формирования общественного сознания и воспитания будущих поколений в тех рамках, в которых мы бы хотели подарить им это будущее.

Таким образом, можно сделать вывод: чтобы изменить что-то в современном укладе общества и системы, в которых мы живем, необходимо «начать сначала» - изменить идеологию общества и его сознания. В связи с этим перед наукой стоит острый междисциплинарный вопрос - кто должен стоять во главе пути нравственных перемен не только в бизнесе, но и в отношениях между людьми? Об этом стоит задуматься каждому.

\section{Список литературы}

Швецов Ю.Г. 2011. Понятие нравственности в обществе и экономике. Проблемы учета и финансов. № 2. С. 3-8.

ALIKPEROVA Natal'ya Valer'evna, Cand.Sci. (Econ.), Senior Lecturer of the Department of Sociology, History and Philosophy, Financial University under the Government of the Russian Federation (49 Leningradsky Ave, Moscow, Russia, 125993); Leading Researcher of the Laboratory of Behavioral Economics Studies, Institute of Social and Economic Studies of Population, Russian Academy of Sciences (32 Nakhimovsky Ave, Moscow, Russia, 117218; natalie_danilina@mail.ru)

\section{ECONOMIC MORALITY - THE FOUNDATION OF SUSTAINABLE DEVELOPMENT OF THE COUNTRY AND SOCIETY}

Abstract. The economic life of modern Russia poses a number of pressing issues, among which the problem of creating morality in society and in economy, which is the foundation of sustainable, full-fledged, effective development of any state, becomes particularly important. The relevance of this issue is exacerbated by the problems that we have seen in Russia in recent decades. They are the high level of economic crime and economic exploitation resulting from greed and selfishness of some business representatives, sometimes with the help of government officials; widespread corruption; the growth of the shadow economy; the fall of moral foundations, the decline in education, health, science, culture. An immoral society leads to an inefficient economy. Economic morality is at the heart of many human virtues, one of which is financial literacy.

Keywords: economic morality, economics, society, financial literacy, economic development 